\title{
MODULUS OF ELASCITY OF UNFIRED RAMMED EARTH
}

\author{
Barbora Mužíková*, Tereza Plaček Otcovská, Pavel Padevět \\ Czech Technical University in Prague, Faculty of Civil Engineering, Thakurova 7, 16629 Prague 6, Czech \\ Republic \\ * corresponding author: barbora.muzikova@fsv.cvut.cz
}

\begin{abstract}
The article is focused on measurement and evaluation of elastic modulus of unfired rammed earth and determination of stress-strain curve in compressive test. Sets of different containt of clay, sand and water were made and their properties were evalueted and compared. It was found out that for the hightest elascity modulus is ideal the ratio of sand and clay around $75 / 25$ up to $80 / 20$, the sets with montmorillonite clay had substantialy smaller value of elascity modulusthan the sets with illite-kaolinite clay and the ideal content of water for sand/clay ratio 75/25 is around 0.295.
\end{abstract}

KEYWORDS: Rammed earth, elastic modulus, mechanical properties, stress-strain curve.

\section{INTRODUCTION}

Nowadays utilization of the unfired earth as a building material is rising. The reason of the trend is mainly the fact that unfired earth is according to the principles of sustainable building development. It is environmentally friendly thanks to using of the final product, there is no need to produce any intermediate products. More over unfired earth building is a hundred per-cent recyclable. On the other hand, the mechanical behavior of the material is not described enough to use the data for designing in practical engineering. This was caused by the leaving the rammed earth as a building material in the time when the characteristics of other materials started to be investigated.

Due to this fact, there are no standards for designing such constructions. That is why the only way how to build such buildings is to have some experience with the material and use gain knowledge in other constructions. Nowaday few researches start to pay attention (for example [1-4]) on the topic of unfired earth. Worldwide there is only a few companies that are capable to build unfired earth house with all requirements of modern living comfort.

One of these constructions is a visitor centre in southwest Wyoming (Fig. 1). It is built of $2500 \mathrm{~m}^{3}$ rammed earth. The energy is gained from the renewable sources - photovoltaic cells, five wind turbines and geothermal system unsuring the heating and cooling of the building. Onother example can be a family house in New Mexico (Fig. 2). There are two big monolithic walls made of rammed earth. Over 150 tuns of material were used to build these two walls. The color of layer take turns to look like a rock cliff.

There are also very old examples of rammed earth construction (such as The Great Wall in Chine, Mayen pyramid in Mexico) and even brand new construction are built. There is a map of unfired earth constructions worlwide in the Fig. 3. The orange color are areas where the unfired earth is a traditional building material. The white marks are the unfired earth constructions that are stated in the UNESCO list. As you can see from the Fig. 3 unfired rammed earth is used in different climatic zone in the wold [5-10].

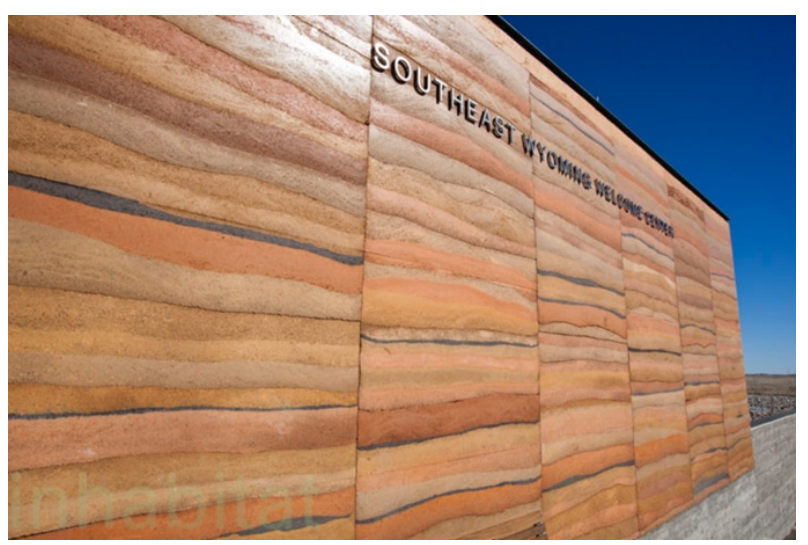

FiguRE 1. The tourist centre in Wyoming is built of rammed earth [11].

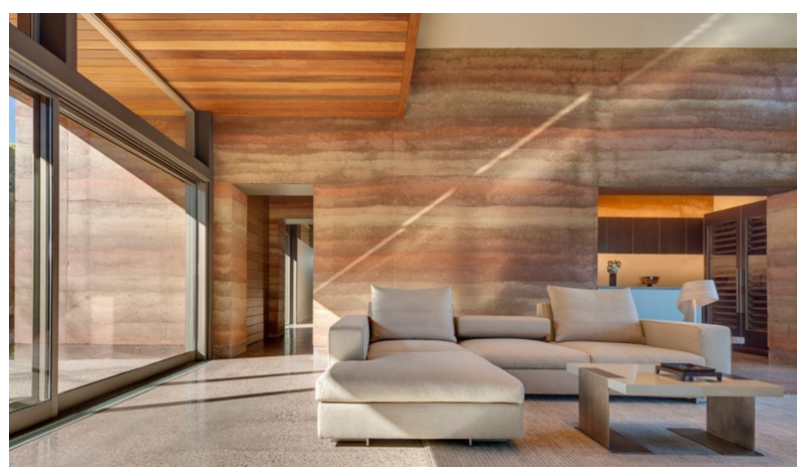

Figure 2. The family house in New Mexico [12.

\subsection{Properties of the MATERIAL}

As it was written above rammed earth brings some advantages and of course even disadvantages compared to commonly used building materials such as concrete and steel. 


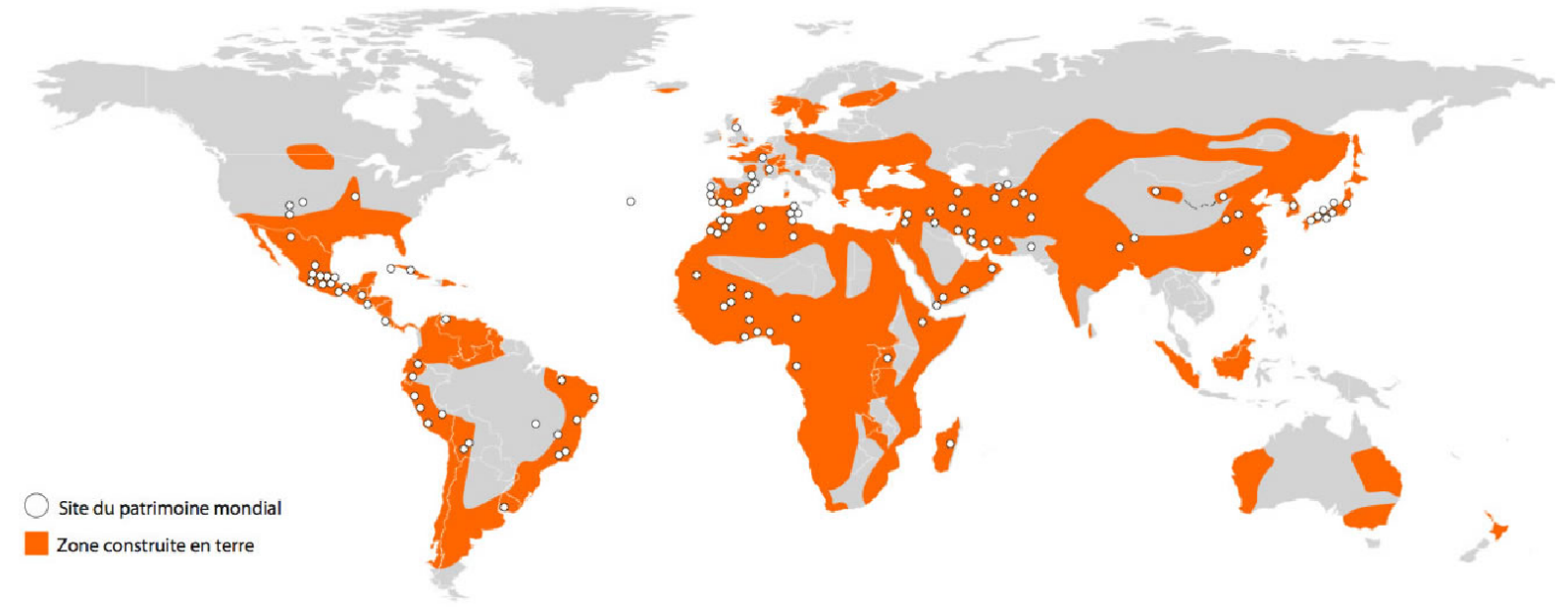

FiguRE 3 . The orange areas are the places where unfired earth is a typical building material and white ones are stated in the UNESCO list [10.

First of all, lets take a look at the advantages. The material is according to the principles of sustainable development, there are no intermediate products - it is direct use of the final product, the building material (in case that there are no stabilisation such as lime or cement) is a hundred procenr recycable and it is a local material. These were the advanteges in the respect of ecology. Another properity of unfired earth is that it is able to balances air humidity in rooms. The loam in unfired earth walls is able to absorbe and desorb humidity faster and greater extent than any other materials. From this results keeping very healty living condition with reduced humidity in summer and elevated humidity in winter.

The wall of rammed earth (as other heavy materials) stores heat. It can balance indoor climate in areas with hight diurnal temperature differences [13. Another advantages is absorbing pollutants, cleaning the indoor air and shielding high frequency light. We can not forget to mention the fire resistant of unfired earth. The biggest development of massive unfired earth houses building was at the area of the Czech Republic in the beginning of $17^{\text {th }}$ century. It was caused by big fires that destroyd wooden houses. Even so called "Fire patent" was published by Marie Terezie. It was ordering to have brick kitchen and chimney - built from unfired bricks [9]. More over earth material preservs timber and other organic materials and it is ideal to do-it-yourself constuction - in this case it is inexpensive.

On the other hand there are also disadvanteges of the material. From the authors' point of view, the main one is a prejudice, skepticism and lack of trustworthy informations about unfired earth worldwive among laymen and even among civil engineers. This is conected to the fact that unfired earth is not a standardises building material. Next the material is not water resistant. It must by shetltered against rain and frost, especialy in its wet state. The sheltering can be done by roof overhangs, dampproof courses or appropriate surface coatings [14]. Another diadvantage is shringing of the material during its drying [7, 15, 16.

\section{Composition of Rammed Earth}

The material that we need for creating rammed earth construction is a loam. Loam is a product of erosion from rock. The composition and varying properties of loam depend on local conditions. Loam is a mixture of clay, silt and sand and sometimes contains larger aggregates like gravel and stones. The particles can be sorted according to diameter: particles with diameters smaller than $0.002 \mathrm{~mm}$ are called clay, those between 0.002 and $0.06 \mathrm{~mm}$ are called silt, and those between 0.060 and $2.000 \mathrm{~mm}$ are called sand. Particles of larger diameter are termed gravels and stones. Like cement in concrete, clay function is to binde all larger particles in the loam. Other larger parts silt, sand and aggregates constitute the fillers in the loam. Depending on which of the three components is dominant, we can differentiate clayey, silty or sandy loam.

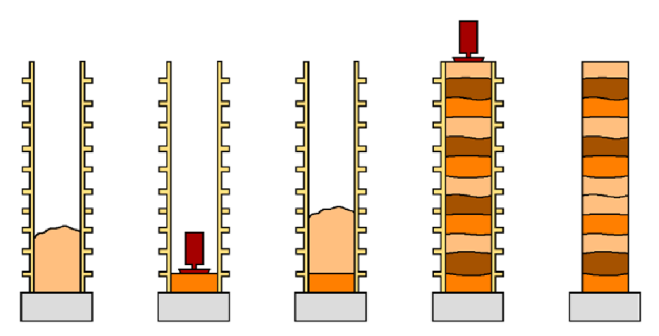

FigURE 4. The process of building a rammed earth wall. 


\begin{tabular}{cccccc}
\hline $\begin{array}{c}\text { Set } \\
{[-]}\end{array}$ & $\begin{array}{c}\text { Sand/Clay Ratio } \\
{[\% / \%]}\end{array}$ & $\begin{array}{c}\text { Water-Clay Ratio } \\
{[-]}\end{array}$ & $\begin{array}{c}\text { Pcs of specimens } \\
{[-]}\end{array}$ & $\begin{array}{c}\text { Bulk density } \\
{\left[\mathrm{kg} / \mathrm{m}^{3}\right]}\end{array}$ & $\begin{array}{c}\text { Type of clay } \\
{[-]}\end{array}$ \\
\hline GEM I & $80 / 20$ & 0.370 & 4 & 2073 & montmorillionite \\
GEM II & $75 / 25$ & 0.370 & 6 & 2040 & montmorillionite \\
GEM III & $75 / 25$ & 0.295 & 6 & 1929 & montmorillionite \\
KR II & $75 / 25$ & 0.370 & 11 & 2134 & illite-kaolinite \\
KR III & $80 / 20$ & 0.400 & 12 & 2138 & illite-kaolinite \\
S III & $75 / 25$ & 0.295 & 4 & 2170 & illite-kaolinite \\
S IV & $85 / 15$ & 0.370 & 6 & 2179 & illite-kaolinite \\
S V & $75 / 25$ & 0.335 & 6 & illite-kaolinite \\
\hline
\end{tabular}

TABle 1. Composition of used mixtures.

\subsection{Clay}

The clay is a product of erosion of feldspar and other minerals. The basic types of clay are known based on the way of creation. These are kaolinite, illite and montmorillionite. They differ in the lamellar structure. The clay changes the properities of the final product mechaical properties and even the colour is different as can be seen in the Fig. 5

\subsection{SAND}

Sand and gravel are used as fillers. They are described by the graph of grain size distribution.

\subsection{WATER}

Water activates the binding forces of the clay. The amount of mixing water has influence on the properities of the final product.

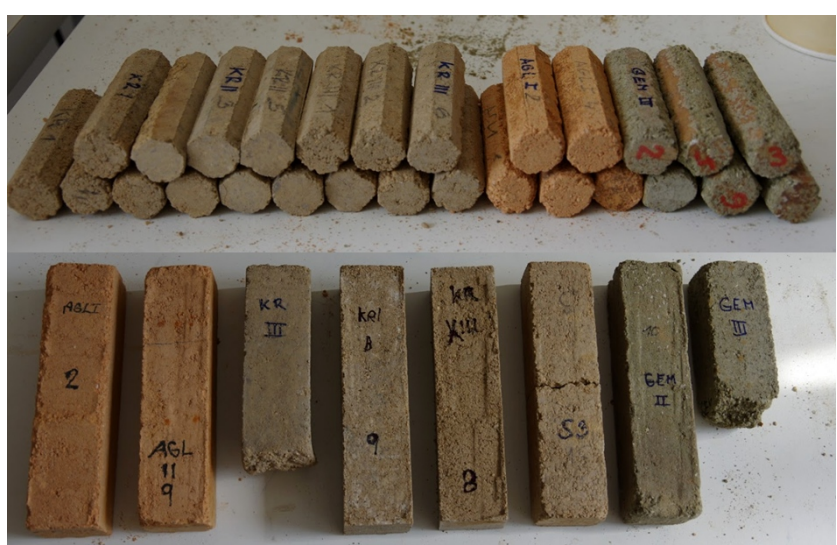

Figure 5. Different type of used clay in specimens.

\section{Production of Specimens}

The material for building specimens is loam and mixing water. That means it is a mixture of sand, clay and water. The loam is made in the laboratory, that means the chosen type of clay and sand (of known grain size distribution) are mixed together to create loam of exactly known composition to compare changes in composition with changes of mechanical properties of the final product. The amount of mixing water is determined depending on the amount of clay, and it is expressed by the water-clay ratio.

The process of building rammed earth wall is as follows. First of all, the framework is built, then the first layer of rammed earth is filled in. Secondly the layer of moist earth is compressed by a tamper. Then next layers of moist earth are added and compressed up to the top of framework. Finally, the framework is removed and the result is a hard monolithic wall. The principle is shown in Fig. 4

Eight different prescriptions were tested for determining modulus of elasticity $E$. Sets GEM with montmorillonite clay and sets $S$ and $K R$ with illite-kaolinite clay, sets differed in the ratio of sand and clay and in the water-clay ratio. The composition of the prescription is described in Table 1 There are names of sets in the first column, then sand/clay ratio, water/clay ratio, the pieces of used specimen is in the forth column, average bulk density of specimens and type of used clay in the last one column.

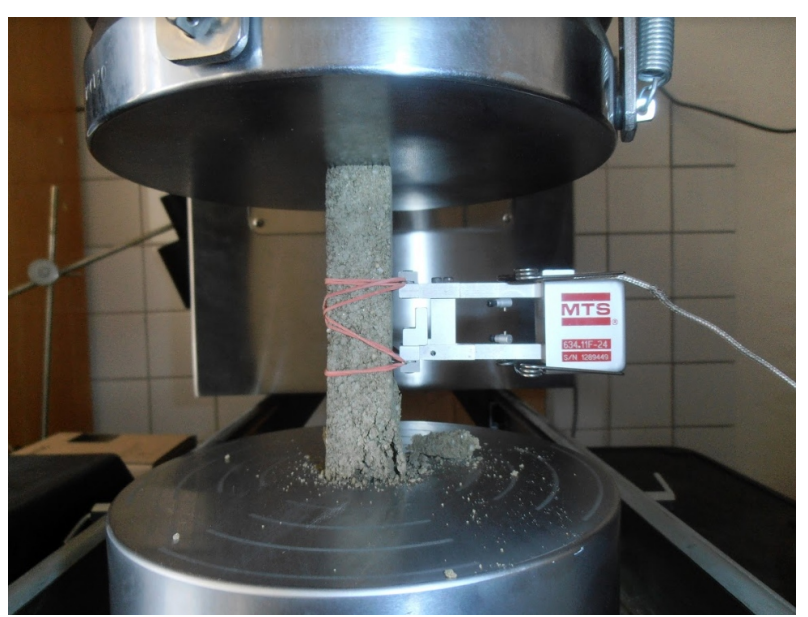

FiguRE 6. Testing of specimens: compressive test.

The laboratory produce of specimens is similar to the building of real constructions. Firstly the prescription is defined as a ratio between sand (the filler) and clay (the binder) and the water-clay ratio is determined. Secondly the compounds were mechanically mixed together, then the moist earth en mixture was 


\begin{tabular}{cccccc}
\hline $\begin{array}{c}\text { Set } \\
{[-]}\end{array}$ & $\begin{array}{c}\text { S/C - w } \\
{[-]}\end{array}$ & $\begin{array}{c}\text { Type of Clay } \\
{[-]}\end{array}$ & $\begin{array}{c}\mathrm{f}_{c} \\
{[\mathrm{MPa}]}\end{array}$ & $\begin{array}{c}\mathrm{f}_{t} \\
{[\mathrm{MPa}]}\end{array}$ & $\begin{array}{c}\mathrm{E} \\
{[\mathrm{MPa}]}\end{array}$ \\
\hline GEM I & $80 / 20-0.370$ & montmorillionite & $1.274 \pm 0.157$ & $0.072 \pm 0.008$ & $43.293 \pm 6.865$ \\
GEM II & $75 / 25-0.370$ & montmorillionite & $1.211 \pm 0.173$ & $0.075 \pm 0.007$ & $33.548 \pm 7.460$ \\
GEM III & $75 / 25-0.295$ & montmorillionite & $1.466 \pm 0.433$ & $0.045 \pm 0.005$ & $33.528 \pm 7.442$ \\
KR II & $75 / 25-0.370$ & illite-kaolinite & $1.150 \pm 0.096$ & - & $54.584 \pm 16.856$ \\
KR III & $80 / 20-0.400$ & illite-kaolinite & $1.077 \pm 0.104$ & - & $61.039 \pm 22.202$ \\
S III & $75 / 25-0.295$ & illite-kaolinite & $2.017 \pm 0.029$ & $0.143 \pm 0.009$ & $99.176 \pm 12.200$ \\
S IV & $85 / 15-0.370$ & illite-kaolinite & $5.890 \pm 0.067$ & $0.073 \pm 0.005$ & $37.356 \pm 17.075$ \\
S V & $75 / 25-0.335$ & illite-kaolinite & $2.165 \pm 0.037$ & $0.127 \pm 0.008$ & $74.339 \pm 19.428$ \\
\hline
\end{tabular}

TABLE 2. Measured modulus of elascity $E$.

layer by layer pressed in to the mould by the drill or manually by a steel block. The specimens were removed from the mould and set in to the climatic chamber where the stable conditions were settled. Compressive tests (specimens of size $20 \times 20 \times 100 \mathrm{~mm}$ ) were made after a month after the produce. The pictures from the testing are shown in the Fig. 6] and 7 .

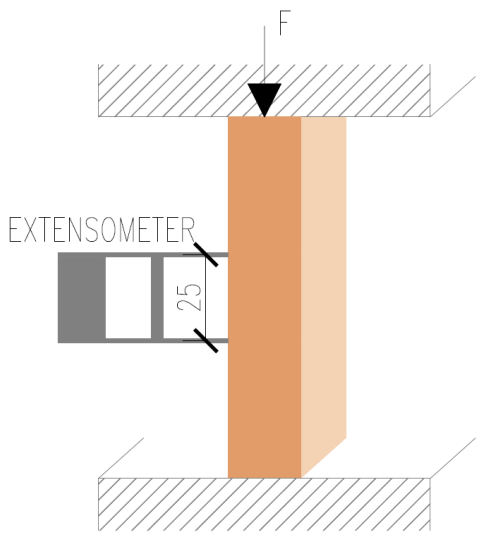

Figure 7. Compresive strenght test with extesometer that records displacements $\delta$ on the specimens (range $25 \mathrm{~mm})$.

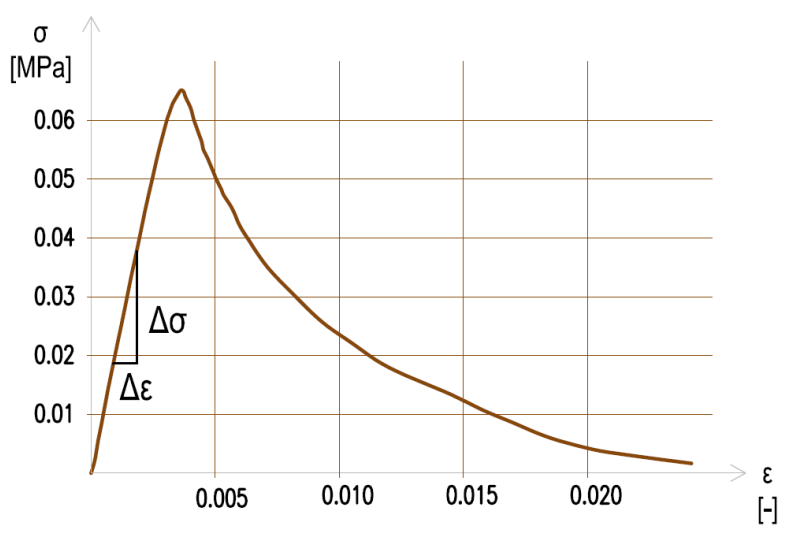

Figure 8. Principle of determinig of modulus of elascity from $\sigma-\varepsilon$ curve.

\section{Method of Determining E}

Test for determining the static modulus of elasticity was the compresive strenght test. The loaddisplacement curve data were recorded during the test. From these data the stress-strain curve was calculated and then the modulus of elasticity was evalueted. The static modulus of elasticity (so called Young's modulus) $E$ is a material property, that describes stiffness. Mechanical deformation puts energy into a material. The energy is stored elastically or dissipated plastically. The way a material stores the energy is summarized in stress-strain curve ( $\sigma-\varepsilon$ curve) that can be determined from load-displacement curve (F- $\delta$ curve). Stress is defined as force per unit area and strain as elongation per unit length. Graphically the modulus of elasticity can be defined as a slope of the linear portion of the stress-strain curve. The modulus of elasticity is defined by the Hooke's law, this law says that for elastically deformation the stress $\sigma$ is directly proportional to strain $\varepsilon$ :

$$
\sigma=E \cdot \varepsilon
$$

The stress-strain curve for GEMI set is show in the Fig. 8. It can be seen that the elasticity modulus can be determined as:

$$
E=\Delta \sigma \div \Delta \varepsilon
$$

The material behaviour is linear elastic, the stressstrain curve in the loading part has a shape of linear curve from the beginning to $0.8 f_{c}$. Due to the fact it was supposed that tangent modulus and secant modulus are of the same value.

\section{Results FROM THE Measurements}

The arithmetic mean and the standard deviation for each set were settled from the measured values, they are in Table 2. There are the compositions of the sets, their compressive and tensile bending stregths ( \pm standard deviation) [17-19] and the evalueted 


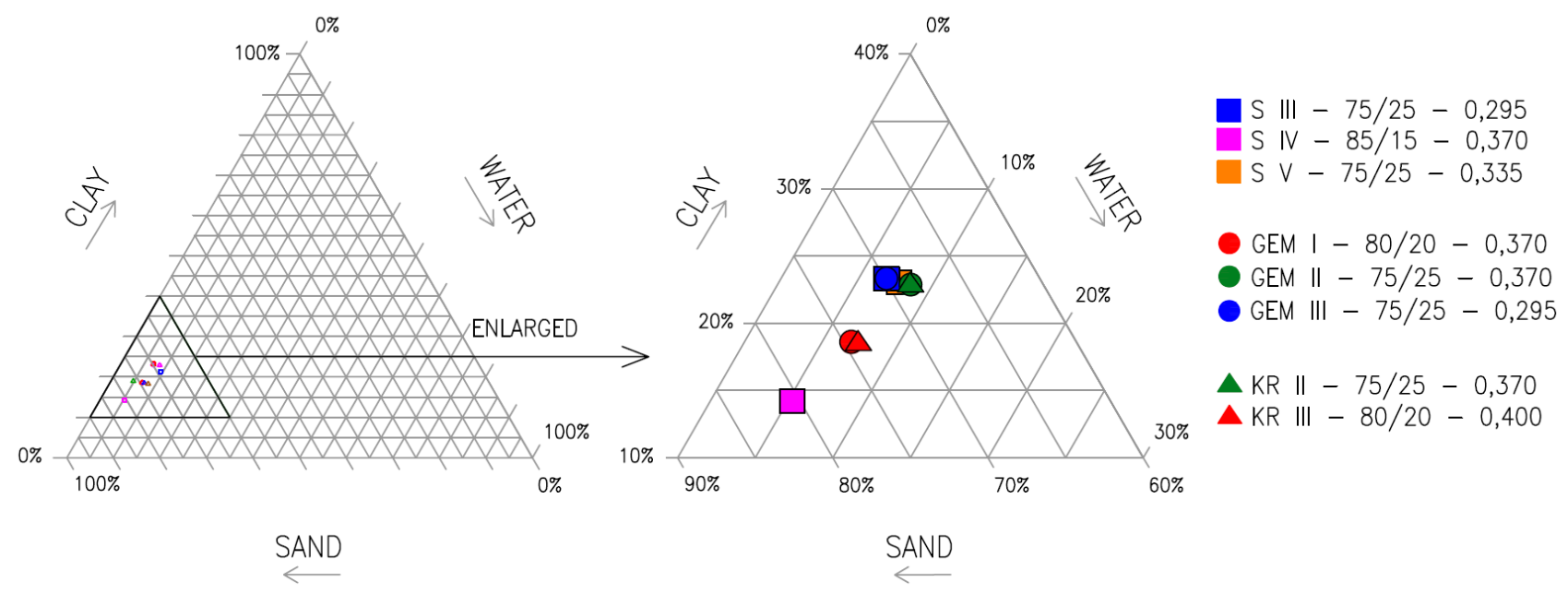

Figure 9. Prescription of used recepises in triangle diagram.

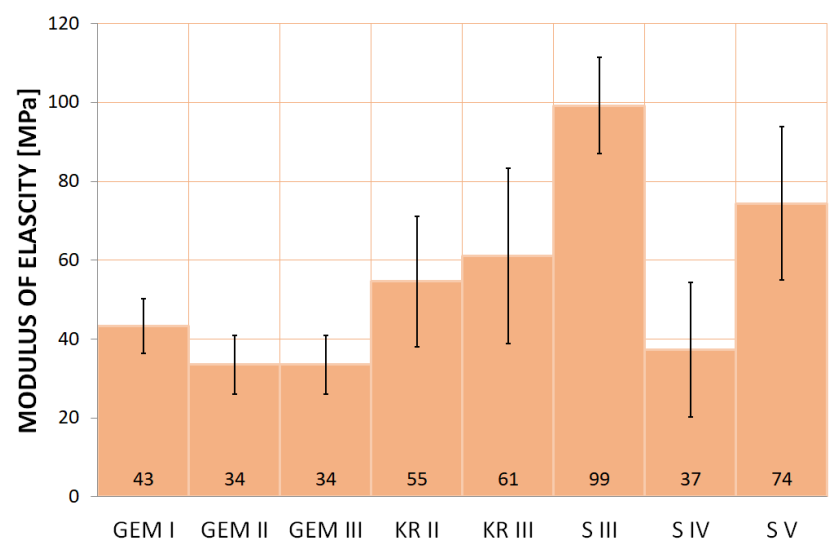

Figure 10. Comparing values of elascity modulus for all sets.

elascity modulus ( \pm standard deviation). Fig. 10 compares modulus of elascity of each set in a chart where the values are in $M P a$.

The recepis are shown in the triangular diagram (Fig. 9) where three components of the mixture (sand, clay and water) are expresed by percent and are on the axis of the diagrame. The composition and the difference between the prescription can bee senn from the diagram.

\subsection{Impact of Sand and Clay Content}

The set $S I V$ had the minimum content of clay and water and maximum content of sand $(85 / 15-0.370)$. Let us remember that the amount of water is settle by the water-clay ratio that means the less clay is used the less water is with same water-clay ratio. The clay that was used was the illite-kaollinite clay. This set reached the minimum value of illite-kaolinite clay sets $37.356 \pm 17.075 \mathrm{MPa}$.

Sets GEM II and KR II contained the maximum of water and minimum of sand, the ratio is the same at both sets $(75 / 25-0.370)$. They differed in used clay. Illite-kaolinite clay was used at $K R I I$ and montmo- rillonite at GEM II. The set GEM II and GEM III reached the minimum value of all sets $33.548 \pm 7.460$ and $33.528 \pm 7.442 \mathrm{MPa}$ and the set KR II reached the second minimum value $54.584 \pm 16.856 \mathrm{MPa}$ of sets with illite-kaolinite clay.

As a result it seems that the ideal ratio of sand and clay is around $75 / 25$ up to $80 / 20$.

\subsection{Impact of Type of Used Clay}

Two types of clay were used - illite-kaolinite and montmorillonite clay. Take a look to already mentioned sets GEM II and KR II. The ratio of clay, sand and water was the same $(75 / 25-0.370)$, but the elascity modulus of $K R I I$ with illite-kaolinite clay is 1.6 times higher.

Another sets GEM III and $S$ III had the same ratio of clay, sand and water $(75 / 25-0.295)$ and again they differed in type of clay. Illite-kaolinite clay was used at $S$ III and montmorillonite at GEM III. The elascity modulus of $S I I I$ with illite-kaolinite clay is nearly 3 times higher.

The sets with montmorillonite clay had substantialy smaller value of elascity modulus so the type of used clay in loam is very important for the mechanical properies of the final product.

\subsection{Impact of Water Content}

The set $S I I I, S I V$ and $K R I I$ had the same ratio of sand and clay - 75/25. The differed in amount of mixture water $-0.295,0.335$ and 0.375 . The values of $E$ were $99.176 \pm 12.202 \mathrm{MPa}, 37.356 \pm 17.075 \mathrm{MPa}$ and $54.584 \pm 16.856 \mathrm{MPa}$. So evidently, the optimal value of water-clay ratio is around 0.295 for sand/clay ratio $75 / 25$.

\section{Conclusions}

Sufficient data of rammed earth properties in relation to its composition have to be find out for extension of these constructions. The article was focused on evalueting elascity modulus of different sets of rammed 
earth. The main data that were found about dependence elascity modulus and composition of clay, sand and mixing water:

- the ideal ratio of sand and clay is around 75/25 up to $80 / 20$,

- the sets with montmorillonite clay had substantialy smaller value of elascity modulusthan the sets with illite-kaolinite clay,

- the ideal content of water for sand/clay ratio $75 / 25$ is around 0.295 .

\author{
LIST OF SYMBOLS \\ $E$ Elascity modulus [MPa] \\ $F$ Load force $[\mathrm{kN}]$ \\ $f_{c} \quad$ Comressive strength $[\mathrm{kPa}]$ \\ $f_{t}$ Tensile bending strength $[\mathrm{kPa}]$ \\ $\delta$ Displacement [mm] \\ $\varepsilon \quad$ Strain $[-]$ \\ $\varrho$ Bulk density $\left[\mathrm{kg} \mathrm{m}^{-3}\right]$ \\ $\sigma$ Stress [kPa] \\ $G E M$ Sets with montmorillionite clay \\ $S$ Sets with illite-kaolinite clay \\ $K R$ Sets with illite-kaolinite clay
}

\section{ACKNOWLEDGEMENTS}

The research was financial supported by the Czech Science Foundation (GACR No.18-0884S) and by the Faculty of Civil Engineering at CTU in Prague (SGS project No.16/201OHK1/3T/11).

\section{REFERENCES}

[1] H. Araki, J. Koseki, T. Sato. Tensile strength of compacted rammed earth materials. Soils and Foundation (56(2)):189-204, 2016.

[2] L. Miccoli, D. V. Oliveira, R. A. Silva, U. Muller. Static behaviour of rammed earth: experimental testing and finite element modelling. Materials and Structures (48(10)):43-56, 2015.

[3] Q. Liu, T. L. Tong. Engineering properties of unstabilized rammed earth with different clay contents. Journal of Wuhan University of Technology: Materials Science (32(4)):914-920, 2017.

[4] R. El-Nabouch, Q. Bui, O. Ple, P. Perrotin. Characterizing the shear parameters of rammed earth material by using a full-scale direct shear box. Construction and Building Materials (171):414-420, 2018.
[5] B. Little, M. Morton. Building with Earth in Scotland: Innovative Design and Sustainability. First printing. Scottish Executive Central Research Unit, 2001.

[6] J. Norton. Building with Earth, A Handbook. First printing. Intermediate Technology Development Group Limited, 1986.

[7] G. Minke. Building with Earth - Design and Technology of Sustainable Architecturer. Second printing. Birkhauser Publishe, 2006.

[8] P. Suske. Nepalena hlina v moderni architekture. Dokument ERA21: ekologie, realizace, architektura (2):69-70, 2004.

[9] I. Zabickova. Hlinene stavby. First printing. Era vydavatelstvi, 2002.

[10] CRAterre - cultures, constructives at developpement durable. 2017 Architecture de terre dans le monde. http://craterre.org

[11] Sirewall. Sirewall inspiration ki,t 2017. http://sirewall.com/

[12] R Reck. Rammed/earth construction gets luxurz makeover, 2015.

http://www.pagethink.com/v/blog-detail/ Rammed-Earth-Construction-is-Cool-Again-and-Hot- / $47 /$

[13] X. Dong, V. Soebarto, M. Griffith. Strategies for reducing heating and cooling loads of uninsulated rammed earth wall houses. Energy and Buildings (77):323-331, 2014.

[14] Q. Bui, J. Morel, B. V. Reddy, W. Ghayad. Durability of rammed earth walls exposed for 20 years to natural weathering. Building and Environment (44(5)):912-119, 2009.

[15] M. Rauch. Refined earth construction and design with rammed earth. Edition detail. Munich, 2015.

[16] Kianfar, Ehsan, V. Toufigh. Reliability analysis of rammed earth structures. Construction and Building Materials (127):884-895, 2016.

[17] T. Otcovska, P. Padevet. Dependence of tensile bending strength of rammed earth on used clay composition and amount of mixture water. Modern Methods of Experimental and Computational Investigations in Area of Construction II pp. 48-53, 2017.

[18] T. Otcovska, P. Padevet. Dependence of compressive strength of rammed earth on used clay composition. Experimental Stresss Analysis 2016.

[19] I. Zabickova, T. Otcovska, P. Padevet. Compressive strength of unburned clay masonry. Modern Methods of Experimental and Computational Investigations in Area of Constructions pp. 31-34, 2016. 